\title{
Budget Allocation System of a Highly Urbanized Local Government Unit in Central Luzon, Philippines
}

\author{
Evangeline B. Lorenzo ${ }^{1}$, Darwin P. Paguio ${ }^{2 *}$, John Mark R. Asio ${ }^{3}$ \\ ${ }^{1}$ Budget Department, Local Government Unit of Olongapo City. Philippines. \\ ${ }^{2}$ Academic Affairs Office, Gordon College. Olongapo City, Philippines \\ ${ }^{3}$ Research Development and Community Extension Services, Gordon College. Olongapo City, \\ Philippines.
}

Article History
Received:
23.09 .2021
Revised:
20.10 .2021
Accepted:
06.11 .2021
*Corresponding Author:
Darwin P. Paguio
Email:
paguio.darwin@
gordoncollege.edu.ph

This is an open access article, licensed under: $\mathrm{CC}-\mathrm{BY}-\mathrm{SA}$
Abstract: The study determined the local planning and budget process of a highly urbanized local government unit (LGU) in Central Luzon, Philippines. It involves all department concerns and civil society organizations (CSOs) that use the City's local governance performance management system (LGPMS). The researchers used a descriptive research study to obtain the necessary data from a survey to seventy-five (75) rank and file employees. The researchers used a purposive sampling technique to gather the respondents involved in planning, budgeting, and managing programs and projects. With a self-made instrument that underwent validity, the researchers gathered the essential data for the study. The data were statistically analyzed using frequency, percentage distribution, analysis of variance (ANOVA), and t-test for independent variables. Preliminary results illustrated that respondents' status was in regular status as division head level, and their years of service were more than sixteen (16) years. The statistical analyses revealed no significant variations in the assessment on the budget allocation system of the local government unit (LGU) as determined on its indicators. The management also agrees that employees work effectively in the budget allocation of the local government unit. The study recommended the orientation and assessment on the current allocation and budget process wherein the department's prioritization can review the objectives and policy decisions.

Keywords: Budget Allocation System, Highly Urbanized City, Local Government Unit, Public Administration, Public Fiscal Administration. 


\section{Introduction}

The budget was first developed several hundred years ago and used within the public sector, as parliaments and other legal bodies had to control public expenditure. It would take until after the Second World War for large private companies to introduce budgets in their organization as an attempt to plan and predict the future [1]. The budget is perhaps the most chosen course of action or inaction by the management and staff across all sectors. In an article about the Japanese local government's participatory budgeting, three identified vital stakeholders possess a varying degree of participation in the budget process [2]. Management levels within the public, private, and the third sector have used the budget as their shield or excuse when confronted or challenged about any decision.

Implementing the budget process must ensure the development and efficient management of public funds. For these reasons, for elaborating an effective and sustainable financial management system at the local government level, units must follow the related policies and procedures and apply a range of reforms that would allow for sound management of public finance. Government budgeting is the critical exercise of allocating revenues and borrowed funds to attain the economic and social goals of the country. Through the budget, the government can prioritize and put its plans, programs, and policies into the constraints of its financial capability as dictated by economic conditions. Atmadja et al. [3] showed that local government commitment does not affect the success of budget management. In addition, Erlina et al. [4] disclose that budget reforms, community participation, and budget user commitment affect budget quality. According to a paper, a budget is an indispensable economic instrument used by the government to facilitate and realize its agenda in a given fiscal year [5]. It is an essential fiscal mechanism for efficient resource mobilization, allocation, and economic management to achieve set objectives. In addition, a paper examined the influence of politics on budget formulation [6]. It revealed that the political business cycle did not exist in the budget formulation.

The local government unit (LGU), like Olongapo City, is guided by the Budget Operations Manual for LGU (BOM for LGUs) issued by the Department of Budget and Management (DBM) on June 10, 2016, under the Local Budget Circular (LBC) No. 112 for all provinces, cities, and municipalities. It emphasizes participatory budgeting, specifically on civil society organizations' emerging roles and engagement (CSOs). Also, strengthening policy-based budgeting by harmonizing development plans, investment programs, and policies and linking the budget are provisions of the Local Government Code of 1991 (Republic Act 7160). At the same time, it uses performance information in appropriation documents to link funding to results and provide a framework for more informed resource allocation and management. Furthermore, streaming local budget forms and accounts is consistent with the revised accounts for LGUs as prescribed under the Commission on Audit.

This study aims to deliver a primary consideration on how an LGU advances and organizes approaches, procedures, and measures employed in the preparation, authorization, review, execution, and accountability of local budget operations. This idea pertains to Section 354 of Republic Act No. 7160 (RA 7160) under the guidelines stated on the Budget Operations Manual for LGU (BOM for LGUs). Moreover, this study will remind the LGU that they need the genuine participation of people through CSOs in the planning and budgeting processes of the City. Moreover, this study seeks to identify how effective and efficient the budget allocation system of Olongapo City's Local Government Unit is as a basis in funding priority programs and projects.

\section{Literature Review}

Researchers define a budget as expressing expectations and commitments within an organization regarding financial consequences for an upcoming time [7]. In the representation of Yahya et al. [8], several factors influence the behavior of legislators in budget development. Essentially, budgets express expectations, as Greve [1] emphasized, budgets are futuristic as it attempts to foresee the forthcoming based on a given set of measures. However, what differentiates them is that budgets allocate responsibility (commitment); for example, the head of the department is responsible for his/her part of the budget. It can also be perceived as a decision that when the executive management accepts a budget, they automatically decide what is for the future, a trait not possessed by the forecast. In a related context, the influence of the concerned matter does not always run into budgetary autonomy. However, budgeting decisions can affect the issue or phenomenon in varying degrees [9]. Also, some researchers identified three capacities where the local government functions effectively. 
These include informing the citizens, complying with the responsibilities, organizing and networking with other stakeholders, and making the planning and budgeting process feasible [10].

According to Isaac et al. [11], budgeting is a crucial policy tool for public management and management of a firm. It is an accustomed activity to many since our private lives and businesses, government, and voluntary groups practice it. A study also emphasized that good governance has a significant effect on the development of budget allocation [12]. Additionally, another paper also showed that budget allocation significantly affects poverty reduction performance [13]. Furthermore, an investigation revealed that 499 districts/ cities in Indonesia have a budget cycle in all components of locally owned revenues [14]. There are some of the crucial roles of budget in the national economy. They prioritize the allocation of public resources, achieving policy goals through prudent financial planning, establishing accountability regarding the usage of the taxpayer money. Financial controls to ensure compliance with rules and increase efficiency. A related article discussed the importance of strengthening the internal revenue allotment system in the Philippines to benefit the more significant part of the country [15]. In another perspective, a research paper they showed some peculiar findings regarding governments' participatory budgeting concepts [16]. It showed both promising and practical answers and negative and unruly ones. However, an article identified three problems that municipal council members encountered during the budget deliberation [17]. From these problems, the author provided some critical recommendations to address them. Also, in a local study in the Philippines, barangay officials can execute local budgeting responsibilities together with preparation, authorization execution, and accounting [18]. In a different point of view, Fortuna [19] disclosed that the budgeting practices of local government units impact the profitability of enterprises in their location. In the concept of the "bottom-up budgeting" program in the Philippines, researchers showed that participation in the program is purely political but does not mean a potent tool for democratic exercise [20]. A government's budget reflects its vision, strategy, and priorities. In a related context, Rokhman [21] indicated that budget participation affects the performance of local government officials. However, managing a budget process that is inclusive, efficient, and transparent can be challenging for department heads and administrators. Budget always plays a crucial role in managing public or private institutions, as efficient management leads to achieving predefined objectives and goals and using its achievement. For these objectives and goals to attain, a study by Reyes et al. [22] suggested using a community-based monitoring system for local planning and budgeting. On the basis of the different literatures mentioned, the researchers decided to study this particular concept of budgeting process which benefits not only the local government unit itself but also the whole community.

\section{Methodology}

\subsection{Research Design}

This study used descriptive research as it involves describing, recording, analyzing, and interpreting the present nature, composition, or phenomena [23]. The focus is on prevailing conditions, or how a person, group, or thing behaves or functions in the present. It often involves some type of comparison or contrast.

\subsection{Respondents}

The population chosen in this study included employees from rank and file such as Department Head, Asst. Department Head, and Division Head at LGU-Olongapo City, since they are directly involved in planning, budget, and management in accomplishing the programs and projects of the City (see Table $1)$.

Table 1. Distribution of the Respondents of the Study

\begin{tabular}{ccc}
\hline Employees Category & No. of Employees & Percentage \\
\hline Department Head & 21 & 27.0 \\
Assistant Dept. Head & 19 & 24.0 \\
Division Head & 39 & 49.0 \\
\hline Total & $\mathbf{7 9}$ & $\mathbf{1 0 0 . 0 0}$ \\
\hline
\end{tabular}


The study utilized the entire population since the employee-respondents were all in the same area and kept the study on its objectives logical and fair judgment. The study used purposive sampling. This sampling technique would enable the researchers to represent the group of people for the study. Researchers need to decide who and what represents the phenomenon. At the same time, how many participants need to be included in the study to explore the research problem [23].

\subsection{Instrument of the Study}

The researchers developed a questionnaire to be able to gather the data needed in the study. It has the following parts:

Part I. Elicit the profile of the employee-respondent.

Part II. Elicit the assessment on the process of the budget allocation system in terms of budget preparation, budget authorization, budget review, budget execution, and budget accountability.

A panel of experts in the budget allocation process validated the researcher-developed questionnaire. They include a representative from the Department of Interior and Local Government (DILG), the Commission on Audit (COA), a Budget Officer, and a research professor to check further the efficacy and adeptness of the questionnaire and improvement of the improvement of its content. Before the actual data gathering, the researchers' pilot tested the questionnaire first to selected local government unit personnel. They were not part of the study for any misconception, misunderstanding, and ambiguous terms and statements.

\subsection{Statistical Analysis}

The researchers organized and processed the data gathered through the Statistical Package for Social Science (SPSS) version 23. The data analyst employed the following statistical techniques to treat the specific problems raised in the study. The frequency and percentage distribution describe the profile of the respondents. The t-test for independent and analysis of variance (ANOVA) assessed the budget allocation system of the local government unit. This study also used a five (5) point Likert Scale for the responses of the employees.

\section{Results and Discussion}

This study aims to assess the local planning and budget process of a highly urbanized local government unit in Central Luzon, Philippines. Based on the gathered data and statistical analysis, the researchers present the following results below.

Table 2 shows the frequency and percentage distribution on the profile of the respondents in terms of employment status. It presents the frequency and distribution of respondents based on their employment status. It shows that fifty-eight (58) or $77.3 \%$ of the total population of seventy-five (75) respondents are regular employees. An equal number of eight (8) participants, or 10.7\%, are of casual and contractual service employment, respectively. In contrast, only one (1) employee, or $1.3 \%$, is of the job order.

Table 2. Distribution on Respondent's Profile According to Employment Status

\begin{tabular}{lcc}
\hline Employment Status & Frequency & Percentage \\
\hline Regular & 58 & 77.3 \\
Casual & 8 & 10.7 \\
Contract of Service & 8 & 10.7 \\
Job Order & 1 & 1.3 \\
\hline Total & $\mathbf{7 5}$ & $\mathbf{1 0 0}$ \\
\hline
\end{tabular}

The result indicates that the majority of them are regular employees, who may have already undergone specific training to improve their work performance in their field of work. As regular employees, they are entitled to attend training related to the budget system in the LGU, such as budget process, budget hearing, and allocation of funds. On the other hand, credibility, loyalty, and 
effectiveness in administration are acquired from varying levels of experience as the stability of workloads may depend on the employment status of the employees.

Table 3 presents the grouping of respondents based on their level of position. It shows that sixteen (16) or $21.3 \%$ of the seventy-five (75) respondents are Department Heads, earning the highest salary among the three while seven (7) or 9.3\% of them are Assistant Department Heads, earning the average salary. Fifty-two (52) or $69.3 \%$ of the respondents are in Division Head, earning the least salary among the three.

Table 3. Distribution on Respondent's Profile According to Position

\begin{tabular}{lcc}
\hline Position & Frequency & Percentage \\
\hline Department Head & 16 & 21.3 \\
Assistant Department Head & 7 & 9.3 \\
Division Head & 52 & 69.3 \\
\hline Total & $\mathbf{7 5}$ & $\mathbf{1 0 0}$ \\
\hline
\end{tabular}

This result indicates that most of the respondents were Division Heads, having a different workload experience with the Department Heads and Assistant Department Heads who were of competent office work. The position level relies on an employee's capability to withhold the load/weight of office work upon assessment or evaluation concerning the existing policies for ranking or appointing.

Table 4 displays the employees' length of service. The largest group of the respondents based on their length of service as employees in the field of administration are those in the service for above 16 years, with thirty (30) or $40 \%$ of the respondents. It also shows that twenty-eight (28) respondents, or $37.3 \%$, have served for 1 to 5 years, whereas fourteen (14) or $18.7 \%$ have been designated for 6 to 10 years. Three (3) or $4.0 \%$ of the population have served for 11 to 15 years.

The result indicates that administrators are trained and skilled enough to administer the institution while many new employees are still in the process of learning the job. The figure indicates that efficiency and effectiveness in the administration profession are acquired through long years of experience, the degree of exposure in the field of work, and understanding and inculcating the mission, role, and initiative toward the office to serve for the betterment of the City.

Table 4. Distribution on Respondent's Profile According to Length of Service

\begin{tabular}{lcc}
\hline Length of Service & Frequency & Percentage \\
\hline $1-5$ years & 28 & 37.3 \\
6-10 years & 14 & 18.7 \\
11-15 years & 3 & 4.0 \\
Above 16 years & 30 & 40.0 \\
\hline Total & $\mathbf{7 5}$ & $\mathbf{1 0 0}$ \\
\hline
\end{tabular}

Moreover, the existence of more employees with a longer period of service in the government indicates their familiarity with the existing policies of the LGU in terms of financial management. These skills are useful for them in making decisions for the good of the management and its people.

Table 5 data showed that the results were scaled as "agree" with an overall mean of 3.98. The employees-respondents ensure that to follow complete staff work in preparing and establishing priorities in allocating resources during investment programming of Programs, Projects and Activities (PPA) as major links to budgeting which is also the basis for preparing the annual budget proposals, allows to practice genuine participation of Civil Society Organization's in the planning and budgeting processes to promote and establish transparency and accountability in all transactions related to Public financial management and encourages participation and involvement of the Civil Society Organizations, as part of the Local Development Council (LDC) and as observers in the Local Finance Committees (LFCs), in the processing of setting directions and allocating available resources 
where the budget fits government policies and priorities, the most cost-effective variants must be selected, and the means of increasing operational efficiency in government must be sought with a weighted mean of $4.15,3.85$ and 3.93 respectively.

Table 5. Assessment on the Process of Budget Allocation System of Local Government Unit According to Budget Preparation

\begin{tabular}{|c|c|c|c|}
\hline & Indicator & $\begin{array}{c}\text { Weighted } \\
\text { Mean }\end{array}$ & $\begin{array}{l}\text { Descriptive } \\
\text { Rating }\end{array}$ \\
\hline 1) & $\begin{array}{l}\text { The Management ensures to follow complete } \\
\text { staff work in preparing and establishing } \\
\text { priorities in allocating resources during } \\
\text { investment programming of Programs, } \\
\text { Projects, and Activities (PPA) as major links to } \\
\text { budgeting which is also the basis for preparing } \\
\text { the annual budget proposals. }\end{array}$ & 4.15 & Agree \\
\hline 2) & $\begin{array}{l}\text { The Management allows the practice of } \\
\text { genuine participation of Civil Society } \\
\text { Organizations in the planning and budgeting } \\
\text { processes to promote and establish } \\
\text { transparency and accountability in all } \\
\text { transactions related to Public financial } \\
\text { management. }\end{array}$ & 3.85 & Agree \\
\hline \multirow[t]{2}{*}{ 3) } & $\begin{array}{l}\text { The management encourages participation and } \\
\text { involvement of the Civil Society } \\
\text { Organizations, as part of the Local } \\
\text { Development Council (LDC) and as observers } \\
\text { in the Local Finance Committees (LFCs), in } \\
\text { the processing of setting directions and } \\
\text { allocating available resources. }\end{array}$ & 3.93 & Agree \\
\hline & $\begin{array}{r}\text { Overall Mean } \\
\end{array}$ & 3.98 & Agree \\
\hline
\end{tabular}

This result indicates that the local government unit on their respective department follows the process of budget allocation system according to budget preparation issued by the Department of Budget and Management (DBM) under Local Budget Circular (LBC), which emphasized the participatory budgeting, specifically on the emerging roles and engagement of the civil society organizations (CSOs), strengthening policy-based budgeting by harmonizing development plans, investment programs, and policies and linking the budget about the provisions of the Local Government Code.

Table 6 illustrates that the budget authorization weighted 4.03, which means that employeesrespondents correspond to the second phase of the local budget process, which ensures the involvement of Civil Society Organizations for the continuity and sustainability of plans and budgets with a weighted mean of 3.81. It also ensures that the Department Heads or Supervisors participate in all budgeting processes and apply for consensus-based decision making in all their projects or programs with a weighted mean of 4.12. Further, it confirms and ensures that the Department Heads or Supervisors participate in all budgeting processes and apply for consensus-based decision making in all their projects or programs with a weighted mean of 4.16 .

The result determined that the local government unit on their respective department supports the implementation of various programs and projects that best promote the development of the City through budget authorization. The government can prioritize and put its plans, programs, and policies into action within the constraints of its financial capability as dictated by economic conditions. 
Table 6. Assessment on the Process of Budget Allocation System of Local Government Unit According to Budget Authorization

\begin{tabular}{llcc}
\hline \multicolumn{1}{c}{ Indicator } & $\begin{array}{c}\text { Weighted } \\
\text { Mean }\end{array}$ & $\begin{array}{c}\text { Descriptive } \\
\text { Rating }\end{array}$ \\
\hline 1) & $\begin{array}{l}\text { The management ensures the involvement of Civil } \\
\text { Society Organizations for the continuity and } \\
\text { sustainability of plans and budgets. }\end{array}$ & 3.81 & Agree \\
2) $\begin{array}{l}\text { The management ensures that the Department } \\
\text { Heads and Supervisors participate in all budgeting } \\
\text { processes and apply consensus-based decision- } \\
\text { making in their projects or programs. }\end{array}$ & 4.12 & Agree \\
3) management encourages enhancing \\
$\begin{array}{l}\text { phe } \\
\text { participative governance in the planning and } \\
\text { budgeting process of the City. }\end{array}$ & 4.16 & Agree \\
\hline Overall Mean & $\mathbf{4 . 0 3}$ & Agree \\
\hline
\end{tabular}

*Legend: 1.00-1.80=Strongly Disagree; 1.81-2.60=Disagree; 2.61-3.40=Somewhat Agree; 3.41-4.20=Agree; 4.21-5.00=Strongly Agree

Table 7 data indicated that ensures to the Department Head or supervisors to attend scheduled meetings and workshops and involved them in the planning and budgeting process of the City with a weighted mean of 4.25 scaled as strongly agree. However, department heads/supervisors evaluate the budget proposals and exercise their oversight function to check if the City delivers the result they committed to deliver with a weighted mean of 4.16 scaled as "agree." At the same time, management explains the meaning of accountability to department Heads/supervisors to reinforce them to commit to performing with a weighted mean of 4.40 and scaled as strongly agree.

Table 7. Assessment on the Process of Budget Allocation System of Local Government Unit According to Budget Review

\begin{tabular}{rlc}
\hline \multicolumn{1}{c}{ Indicator } & $\begin{array}{c}\text { Weighted } \\
\text { Mean }\end{array}$ & $\begin{array}{c}\text { Descriptive } \\
\text { Rating }\end{array}$ \\
\hline 1) $\begin{array}{l}\text { The management ensures to the Department Head } \\
\text { or Supervisors attend scheduled meetings and } \\
\text { workshops. It involves them in the planning and } \\
\text { budgeting process of the City. }\end{array}$ & 4.25 & $\begin{array}{c}\text { Strongly } \\
\text { Agree }\end{array}$ \\
2) $\begin{array}{l}\text { The management enables the Department } \\
\text { heads/Supervisors to evaluate the budget proposals } \\
\text { and exercise their oversight function to check if the } \\
\text { City delivers the results they committed to deliver. }\end{array}$ & 4.16 & Agree \\
3) $\begin{array}{l}\text { The management explains the meaning of } \\
\text { accountability to Department Heads / Supervisors } \\
\text { to reinforce them to commit to performing. }\end{array}$ & 4.40 & $\begin{array}{c}\text { Strongly } \\
\text { Agree }\end{array}$ \\
\hline Overall Mean & $\mathbf{4 . 2 7}$ & $\begin{array}{c}\text { Strongly } \\
\text { Agree }\end{array}$ \\
\hline
\end{tabular}

*Legend: 1.00-1.80=Strongly Disagree; 1.81-2.60=Disagree; 2.61-3.40=Somewhat Agree; 3.41-4.20=Agree; 4.21-5.00=Strongly Agree

The result manifests an overall mean of 4.27 as strongly agreed, which indicates that the local government unit of Olongapo City reviews ordinances authorizing the annual or supplemental appropriations of cities, municipalities, or provinces to determine whether the appropriation ordinance has complied with the budgetary requirements and general limitations outlined in the Local Government Code. 
Table 8 data showed that the results were scaled as "agree" with an overall mean of 3.91. The employees-respondents involved in the Civil Society Organization are to help the City maximize the use of resources and to avoid service gaps due to funding constraints in the implementation of urgent projects to reduce delay. It ensures effective implementation of all programs and the planning and budgeting process to ensure transparency with a weighted mean of 3.89, 3.89, and 3.95, respectively.

This result indicates that the local government unit on their respective department delivery of goods and services to target clients in the most efficient, effective, economical and ethical way which emphasized the participatory budgeting, specifically on the emerging roles and engagement of the civil society organizations (CSOs) that provide a framework for more informed resource allocation and management.

Table 8. Assessment on the Process of Budget Allocation System of Local Government Unit According to Budget Execution

\begin{tabular}{|c|c|c|c|}
\hline \multicolumn{2}{|r|}{ Indicator } & $\begin{array}{c}\text { Weighted } \\
\text { Mean }\end{array}$ & $\begin{array}{c}\text { Descriptive } \\
\text { Rating }\end{array}$ \\
\hline 1) & $\begin{array}{l}\text { The management involves the Civil Society } \\
\text { Organization to help the City maximize the use of } \\
\text { resources and avoid service gaps due to funding } \\
\text { constraints. }\end{array}$ & 3.89 & Agree \\
\hline 2) & $\begin{array}{l}\text { The management involves the Civil Society } \\
\text { Organization in implementing urgent projects to } \\
\text { reduce delay and ensure effective implementation } \\
\text { of all programs. }\end{array}$ & 3.89 & Agree \\
\hline 3) & $\begin{array}{l}\text { The management involves the Civil Society } \\
\text { Organization in the planning and budgeting process } \\
\text { to ensure transparency in the Local Government } \\
\text { Unit. }\end{array}$ & 3.95 & Agree \\
\hline Overa & I Mean & 3.91 & Agree \\
\hline
\end{tabular}

Table 9 illustrated the budget accountability assessment weighted 4.19, which means that employees-respondents observed the proper execution of the budget, officials, and employees involved and followed the law and the rules and regulations of the government agencies.

Table 9. Assessment on the Process of Budget Allocation System of Local Government Unit According to Budget Accountability

\begin{tabular}{lcc}
\hline \multicolumn{1}{c}{ Indicator } & $\begin{array}{c}\text { Weighted } \\
\text { Mean }\end{array}$ & $\begin{array}{c}\text { Descriptive } \\
\text { Rating }\end{array}$ \\
\hline 1) $\begin{array}{l}\text { The management ensures that the Department Head } \\
\text { / Supervisors are aware of the Local Budget }\end{array}$ & 4.40 & $\begin{array}{c}\text { Strongly } \\
\text { Agree }\end{array}$ \\
$\begin{array}{l}\text { Process of the City. } \\
\text { 2) } \begin{array}{l}\text { Department Head / Supervisors are well informed } \\
\text { in the Budget Allocation System of the City }\end{array}\end{array}$ & Agree \\
3) $\begin{array}{l}\text { The management empowers the Department } \\
\text { Heads/Supervisors to participate in the utilization } \\
\text { and allocation of resources with more transparent, }\end{array}$ & 4.12 & Agree \\
accountable, and responsive budget documents. & & Agree \\
\hline Overall Mean & $\mathbf{4 . 1 9}$ &
\end{tabular}


It ensures that the Department Head / Supervisors are aware of the Local Budget Process of the City, are well informed in the Budget Allocation System of the City and empowers the Department Heads/Supervisors to participate in the utilization and allocation of resources with more transparent, accountable and responsive budget documents with a weighted mean of $4.40,4.05$ and 4.12 respectively.

The result determined that the local government unit on their respective department fulfills important functions to carry out several objectives roles of budget in the national economy which prioritize the allocation of the public resources, achieving policy goals through prudent financial planning, establishing accountability regarding the usage of the tax payers' money, and financial controls to ensure compliance to rules and increase efficiency.

Table 10 shows the summary of the Budget Allocation Process of LGU. The data shows the five (5) phases of the budget allocation process assessed by the employees. Respondents were rated "agree" with an overall mean of 4.01 .

Budget preparation was scaled 3.98, second to the lowest among the phases, which indicates that there are instances in this phase that some did not follow accordingly within the system.

Budget authorization resulted in 4.03, which expresses that employees-respondents supported the budget planning and its preparation. It has been discussed during sessions and meetings and willing to implement the said economic growth.

Budget review expressed on the scale of 4.27, the highest score in the assessment regarding the budget allocation process, which manifested that the allocation of the budget established its priorities on what is the need of the City first in improving the needs of the citizens.

Table 10. Summary of the Assessment Process on the Budget Allocation System of Local Government Unit

\begin{tabular}{rlcc}
\hline \multicolumn{1}{c}{ Indicator } & Weighted Mean & Descriptive Rating \\
\hline 1) & Budget Preparation & 3.98 & Agree \\
2) Budget Authorization & 4.03 & Agree \\
3) Budget Review & 4.27 & Strongly Agree \\
4) Budget Execution & 3.91 & Agree \\
5) Budget Accountability & 4.19 & Agree \\
\hline Overall Mean & $\mathbf{4 . 0 1}$ & Agree \\
\hline
\end{tabular}

*Legend: 1.00-1.80=Strongly Disagree; 1.81-2.60=Disagree; 2.61-3.40=Somewhat Agree; 3.41-4.20=Agree; 4.21-5.00=Strongly Agree

However, budget execution was marked as the lowest scaled among the assessment on the budget allocation process. The possibility of this was the project's budget allocation for insufficient budget or fund and if the proposed plans and projects were not supported to be prioritized as the need of the citizens.

Moreover, the budget accountability has been ranked 4.19, which indicates that the employeesrespondents know the consequences of their action upon approval of plans and projects.

The result of the overall weighted mean denotes that the management headed by the department heads and supervisors ensures the work performance of its staff to the extent of their capability to become accountable employees functioning good governance in the budget allocation system of the LGU.

It can be implied that the management agrees that their employees work effectively in the budget allocation system of LGU, which ensures the juridical process of the said system. However, during the informal interview conducted by the researcher, some respondents said that the projected income of the LGU is higher than the actual annual income. In addition, during the budget allocation system, respondents also said that no planning system is being conducted before the budget allocation per department. LGU lacks to establish priorities and allocate resources on all Programs, Projects, and Activities (PPAs) included in the Annual Investment Plan. The Annual Investment Plan (AIP) refers to the annual slice of the Provincial/Local Development Investment Program, which constitutes the 
total resource requirements for all PPAs, i.e., the annual capital expenditure and standard operating requirements of the LGU.

Moreover, respondents also informed the researcher that in the current practice in LGU, the Managements lacks the engagement of the civil society organizations (CSOs) in each phase of the local budget process, which is significant with the implementation of the Local Budget Circular No. 112 (LBC 112) dated June 10, 2016, on Budget Operations Manual for LGU. Furthermore, respondents also informed the researcher that Commission on Audit issued Audit Observation Memorandum (AOM) to LGU, which signifies poor planning within the management.

Table 11 shows no significant differences between the assessment on the budget allocation process of LGU and all the following profile variables: employment status, level of position, and length of service.

The $\mathrm{F}$ values of $0.604,0.767$, and 1.114 with corresponding probability values of $0.615,0.468$, and 0.349 are insignificant at alpha 0.05 . The result means that there is no significant difference between the employment status and the assessment of the employees-respondents on the budget allocation process of the local government unit at Olongapo City. The result signifies that whatever the employment status the employees have at present, it does not affect the process of the budget allocation system.

Table 11. Differences in the Assessment on the Process of Budget Allocation System of Local Government Unit and Profile of the Employee-Respondents

\begin{tabular}{llcccc}
\hline \multicolumn{2}{c}{$\begin{array}{c}\text { Assessment on the Process of Budget } \\
\text { Allocation System of LGU }\end{array}$} & $\boldsymbol{N}$ & Mean & $\boldsymbol{F}$-value & $\begin{array}{c}\boldsymbol{p} \text { - } \\
\text { value }\end{array}$ \\
\hline \multirow{5}{*}{ Employment } & Regular & 58 & 4.07 & & \\
Status & Casual & 8 & 4.27 & & \\
Level of Position & Contract of Service & 8 & 3.90 & 0.604 & 0.615 \\
& Job Order & 1 & 4.07 & & \\
& Department Head & 16 & 4.18 & & \\
& Assistant Department & 7 & 4.23 & & \\
& Head & 52 & 4.03 & & \\
& Division Head & 28 & 4.22 & & \\
Length of Service & 1-5 years & 14 & 4.00 & & \\
& 6-10 years & 3 & 4.09 & 1.114 & 0.349 \\
& 11-15 years & 30 & 3.98 & & \\
\hline
\end{tabular}

On the other hand, there is also no significant difference between the response of the employeesrespondents assessment on the budget allocation system and the position level. It denotes that most division heads process the budget allocation according to the rules and regulations promulgated by the government.

Moreover, the length of service does not significantly affect the assessment on budget allocation, which implies that the employees-respondents follow the proper practice of the present procedure on the budget allocation system and implement it aptly.

The result hereof manifests the sufficient measurement on the assessment on the process of budget allocation system of LGU-Olongapo City whether the employee-respondents are regular employees, belongs to the top management of position, serving the LGU for a longer period, and enjoys the security of tenure in the government. The measurement of the assessment on the process of budget allocation system of LGU-Olongapo City does not solely depend on the profile of the employee respondents.

\section{Conclusion}

Based on the data collected, the researchers presented the following conclusions (1) accordingly, the majority of the employment status were regular. Most of the employees-respondents were division 
heads which most of them had a length of service of sixteen years (16) and above. (2) Based on the budget allocation process assessment, budget review garnered the highest response of strongly agree among the respondents. Budget accountability came in second, followed by budget authorization, budget preparation, and budget execution. All got a response of "agree" among the respondents. (3) There were no significant differences between the assessment on the budget allocation process of LGU and all the following profile variables: employment status, level of position, and length of service. On the other hand, there is also no significant difference between the response of the employees-respondents assessment on the budget allocation system and the position level. It denotes that most division heads process the budget allocation according to the rules and regulations promulgated by the government. Moreover, the length of service does not significantly affect the assessment on budget allocation, which implies that the employees-respondents follow the proper practice of the present procedure on the budget allocation system and implement it aptly.

Based on the conclusions, the researchers endorse the following recommendations: (1) regular status employees, which consist mostly of division heads, should monitor and implement the participatory enhance program to improve further the budget preparation and assessment made by all departments in the local government units. (2) A participative governance mechanism in planning and budgeting is a result of this proposed as an output of the study. The activity consists of orientation/assessment, revision/enhancement, comprehensive training and workshop implementation, and monitoring and updating the current planning and budget process. (3) The systematic mediumterm revenue forecasts should be generated for planning. In general, the budgetary processes were not being completely implemented because of the delay in the data needed to projection resources and concrete establishment of expected output. Moreover, the emerging roles and engagement of the Civil Society Organization in planning and each phase of the Local Budget Process in the LGUOlongapo City were not being imposed as to what is stated and given the emphasis on the Updated Budget Operations manual (2016 edition). (4) The researcher recommends that employees from the rank and file involved in planning and budget management and accredited CSOs be included during the distribution of questionnaires or informal interviews in the future conduct of the study. (5) In assessing the status of the budget allocation system in the LGU, the study recommends in future research that additional indicators that are related to participative governance mechanisms in the planning and budgeting process may be considered and included for future study. It also recommends that the study be compared with other LGU to identify other factors that may be significant in enhancing the current local budget allocation system. (6) With the existing problem that has been raised in this study and during the informal interview, it is recommended that the LGU-Olongapo City employees, particularly the Department Managers shall continuously be educated and shall learn to enforce the law and the rules and regulations of COA, DBM, BLGF, DILG, and other oversight agencies in terms of planning and budgeting process emphasizing the participative governance mechanism. (7) A proposed participatory enhancement program is as a result of this recommended for this study.

\section{References}

[1] J. Greve, Budget, 2nd ed. Lund: Studentlitteratur AB, 2011.

[2] S. Uddin, Y. Mori, and P. Adhikari, "Participatory Budgeting in a Local Government in a Vertical Society: a Japanese Story," International Review of Administrative Sciences, vol. 85, no. 3, pp. 490-505, 2017.

[3] A. T. Atmadja, K. A. K. Saputra, Koand M. K. Koswara, "the Influence of Village Conflict, Village Apparatus Ability, Village Facilitator Competency and Commitment of Local Government on the Success of Budget Management," Academy of Accounting and Financial Studies Journal, vol 22, 2018.

[4] E. Erlina, Z. A. Tarigan, and I. Muda, "Antecedents of Budget Quality Empirical Evidence from Provincial Government in Indonesia," International Journal of Economic Research, vol. 14, no. 12, January 2017.

[5] A. S. Olomola, "State Budgetary Allocations: An Appraisal of Budget Implementation and Effects in Nigerias," StudyMode. [Online]. Available: https://www.studymode.com/ essays/State-Budgetary-Allocation-An-Appraisal-Of-38878936.html. [Accessed: 15-Sep-2021]. 
[6] A. I. A. Moeis, N. D. Nachrowi, A. Ananta, and M. Widjaja, "The politics of district budget formulation in multi-party Indonesia." [Online]. Available: https://ijie.um.edu.my /article/view/25381. [Accessed: 15-Sep-2021].

[7] C. Ax, H. Kullvén, and C. Johansson, Den nya ekonomistyrningen. Liber, 2021.

[8] I. Yahya, M. Z. B. Torong, and I. Muda, "Influence Behavior in Legislature Budget Development of Regions in the Province Of Aceh and North Sumatra," International Journal of Economic Research, vol. 14, no. 8, pp. 147-156, January 2017.

[9] M. R. Talukdar, "Influencing phenomena of local government budgeting decisions in Bangladesh," International Journal of Law and Public Administration, vol. 3, no. 1, p. 38, 2020.

[10] P. K. Panday and S. Chowdhury, "Responsiveness of local government officials: Insights and lessons from participatory planning and budgeting," Asia Pacific Journal of Public Administration, vol. 42, no. 2, pp. 132-151, 2020.

[11] L. Isaac, M. Lawal, and T. Okoli, "A Systematic Review of Budgeting and Budgetary Control in Government Owned Organizations," Research Journal of Finance and Accounting. [Online]. Available: https://www.iiste.org/Journals/index.php/RJFA/article/view/21157. [Accessed: 15Sep-2021].

[12] I. G. S. Kurniawan, M. S. Utama, M. K. S. Budhi, and I. B. P. Purbadharmaja, "The implications of Good Governance Performance, Development Budget Allocation, and Economic Growth Inclusion of People's Welfare in Bali Province.," IOSR Journal of Economics and Finance. [Online]. Available: http://www.iosrjournals.org/iosr-jef/papers/Vol9Issue2/Version-2/E0902024662.pdf. [Accessed: 15-Sep-2021].

[13] Y. Boni, "Effect of poverty Budget Allocation on Poverty Reduction Performance in Baubau City.," International journal of economic perspectives. [Online]. Available: http://ijeponline.org/index.php/journal/article/view/21. [Accessed: 15-Sep-2021].

[14] G. E. Wiguna and K. Khoirunurrofik, "Political Budget Cycle Patterns and The Role Of Coalition Parties in Shaping Indonesian Local Government Spending," Asia-Pacific Journal of Regional Science, vol. 5, no. 1, pp. 41-64, 2021.

[15] J. C. Cuaresma, "Strengthening the Internal Revenue Allotment System Towards Greater Equity in the Philippines," OECD Fiscal Federalism Studies, pp. 163-177, 2019.

[16] A. L. Franklin and C. Ebdon, "Participatory Budgeting in the Philippines," Chinese Public Administration Review, vol. 11, no. 1, p. 60, 2020.

[17] L. A. Villanueva, "Budget Deliberation as Communicative Practice: The case of a rural municipality in the Philippines," International Journal of Asia Pacific Studies, vol. 17, no. 2, pp. 283-319, 2021.

[18] R. G. Dagohoy, "Capabilities and Difficulties of Barangay Officials on Local Budgeting Process," International Journal of Research and Innovation in Social Sciences, vol. 5, no. 5, pp. 325-335, May 2021.

[19] C. P. Fortuna, "Budgeting practices: Its Impact on the Profitability of Small and Medium Enterprises in Isabela," Universal Journal of Accounting and Finance, vol. 9, no. 3, pp. 336346, 2021.

[20] G. A. Maravilla and J. H. Grayman, "Understanding Participatory Budgeting through Formal and Informal Processes of Inclusion: A Case Study in the Philippines," Development in Practice, vol. 30, no. 4, pp. 448-458, 2020.

[21] M. T. Rokhman, "Confirmatory Factor Analysis of Job Relevant Information, Budget and Performance Participation of Apparatus Regional Government of Malang Regency," Jurnal Dinamika Ekonomi Pembangunan, vol. 1, no. 2, pp. 90-98, 2018.

[22] C. M. Reyes, A. R. P. Vargas, and A. A. Arboneda, "Evidence-Based Local Planning and Budgeting Using CBMS," Philippine Institute for Development Studies. [Online]. Available: https://pidswebs.pids.gov.ph/CDN/PUBLICATIONS/pidsdps2050.pdf. [Accessed: 15-Sep2021].

[23] J. W. Creswell and J. D. Creswell, Research design: Qualitative, quantitative, and mixed methods approaches. Thousand Oaks, CA: SAGE Publications, Inc, 2018. 